\title{
VULNERABILITY IN CHILD DEVELOPMENT: INFLUENCE OF WEAK FAMILY BONDS, SUBSTANCE ABUSE AND DOMESTIC VIOLENCE ${ }^{1}$
}

\author{
Daniel Ignacio da Silva², Mariluci Alves Maftum³, Verônica de Azevedo Mazza4
}

\footnotetext{
${ }^{1}$ Extract from the dissertation - Vulnerability in the child development according to nurses in the Family Health Strategy, Universidade Federal do Paraná (UFPR), 2012.

2 Doctoral student, School of Nursing, Universidade de São Paulo. São Paulo, São Paulo, Brazil. E-mail: daniel.silva1076@gmail.com

${ }^{3}$ Ph.D. in Nursing. Coordinator of Scientific Initiation and Academic Integration Program, UFPR. Curitiba, Paraná, Brazil. E-mail: maftum@ufpr.br

${ }^{4}$ Ph.D. in Nursing. Coordinator of the Postgraduate Program in Nursing, UFPR. Curitiba, Paraná, Brazil. E-mail: mazzas@ ufpr.br
}

\begin{abstract}
Exploratory qualitative research with the aim to learn the nurses' understanding of vulnerability in child development. Participants were 39 nurses working at 39 health units in Curitiba, state of Paraná, Brazil. Data were collected by means of semi-structured interviews and analyzed by dialectical hermeneutics. Results showed that, according to the nurses, child vulnerability is influenced by weak family bonds, substance abuse and domestic violence. Study participants report the expression of individual processes that reflect postmodern society, and understand the society-family relationship as a deleterious situation for child development. The use of the concept of vulnerability in the professional lives of nurses and healthcare teams enables a critical analysis of their practice. The application of this concept in childcare allows to restructure the care model, thus overcoming the fragmented and biologicist concept of child development. DESCRIPTORS: Health vulnerability. Child development. Family health. Nursing.
\end{abstract}

\section{VULNERABILIDADE NO DESENVOLVIMENTO DA CRIANÇA: INFLUÊNCIA DOS ELOS FAMILIARES FRACOS, DEPENDÊNCIA QUÍMICA E VIOLÊNCIA DOMÉSTICA}

RESUMO: Pesquisa exploratória qualitativa que objetivou conhecer a compreensão do enfermeiro sobre a vulnerabilidade no desenvolvimento da criança. Os sujeitos foram 39 enfermeiros que trabalham em 39 Unidades Municipais de Saúde em Curitiba, Paraná, Brasil. Os dados foram coletados por meio de entrevistas semiestruturadas e analisados pela hermenêutica dialética. Os resultados apontaram que, segundo os enfermeiros, a vulnerabilidade da criança é influenciada pelos elos familiares fracos, pela dependência química e pela violência doméstica. Os sujeitos da pesquisa relatam a expressão de processos individuais como reflexos da sociedade pós-moderna e compreendem a relação sociedade-família como uma situação adversa ao desenvolvimento infantil. A utilização do conceito de vulnerabilidade no cotidiano profissional do enfermeiro e da equipe de saúde permite uma análise crítica de suas práticas. A aplicação desse conceito no cuidado à criança propicia a reorientação do modelo assistencial e, portanto, a superação do conceito biologicista e fragmentado de desenvolvimento infantil.

DESCRITORES: Vulnerabilidade em saúde. Desenvolvimento infantil. Saúde da família. Enfermagem.

\section{VULNERABILIDAD EN EL DESARROLLO DEL NIÑO: INFLUENCIA DE LOS ESLABONES FAMILIARES DÉBILES, DEPENDENCIA QUÍMICA Y VIOLENCIA DOMÉSTICA}

RESUMEN: Investigación exploratoria cualitativa que objetivó conocer la comprensión del enfermero sobre la vulnerabilidad en el desarrollo del niño. Los sujetos fueron 39 enfermeros que trabajan en 39 Unidades de Salud en Curitiba, Paraná, Brasil. Los datos fueron obtenidos por medio de entrevistas semi-estructuradas, y analizados por la hermenéutica dialéctica. Los resultados apuntaron, según los enfermeros, que la vulnerabilidad del niño es influida por los eslabones familiares débiles, por la dependencia química y violencia doméstica. Los sujetos de la investigación relatan la expresión de procesos individuales como reflejos de la sociedad posmoderna y comprenden esta relación sociedad-familia como situación adversa al desarrollo infantil. La utilización del concepto de vulnerabilidad en el cotidiano profesional del enfermero y del equipo de Salud, permite un análisis crítico de sus prácticas. La aplicación de este concepto en el cuidado al niño propicia la reorientación del modelo asistencial, y así, la superación del concepto biologicista y fragmentado de desarrollo infantil.

DESCRIPTORES: Vulnerabilidad en salud. Desarrollo infantil. Salud de la familia. Enfermería. 


\section{INTRODUCTION}

Linked to socioeconomic factors, child health conditions have challenged society to ensure children basic rights such as protection, health, nutrition, education, sport, leisure and culture. ${ }^{1}$ However, this can only be achieved through broad political and societal commitment that enables social, economic and material conditions for families. ${ }^{2}$

Children in developing countries who live in poor socioeconomic conditions are more vulnerable to health problems. Therefore, the factors that influence children's potential for growth and development must be recognized, such as environment, mothers' education, family income, prenatal situation and organization of health services. It is evident that biological, psychosocial, and environmental factors can negatively and/or positively influence child development. ${ }^{3}$

Child development can be understood as a vital process resulting from interaction between the phenomena of growth, maturation and learning. These phenomena cause qualitative changes in the functions of an individual, which can be seen in skills acquired and behavior changes manifested in physical, intellectual, emotional and social contexts. These changes are expressed in the alterations and acquisition of particular skills and competencies of each stage of a child's life. ${ }^{4}$

It is understood that the absence or deficiency of supportive relationships and affective bonds with caregivers can result in significant impairment of a child's central nervous system and cognitive and emotional functions, which can increase vulnerability in the child's development. ${ }^{5-6}$

Vulnerability can be understood as a set of conditions that make individuals and communities more susceptible to diseases or disabilities, as a result of individual, social and programmatic elements. ${ }^{7}$ In the individual dimension of vulnerability in a child's development, it is understood that an environment without ongoing nurturing relationships, with inadequate and insufficient stimulation and the presence of drugs and violence may be adverse conditions to the child development. ${ }^{5-6,8}$ These situations are spaces of vulnerability, which can be minimized by a supportive environment, defined as: the set of supportive, continuous relationships and affectionate interactions that are necessary to ensure the child's proper development. $^{5}$
By understanding vulnerability, nurses and healthcare teams can recognize the health needs of individuals or communities under their care, making it possible to provide more appropriate interventions. ${ }^{7}$ This study can contribute to advance the nursing practice, since by using vulnerability as a child care technology, nurses can develop care that enables fundamental mechanisms for attaining the intellectual, social, emotional and physical potential of children. ${ }^{5}$

In this sense, in primary health care, nursing can intervene in early childhood, expanding opportunities for the development of children living in areas with social risk. ${ }^{4-5,8}$ Direct action on the determinants of child development may afford better health conditions, increased productive and economic capacity, and responsible citizens as protagonists in the future. ${ }^{9}$

Therefore, the guiding question of this study is: how do nurses understand vulnerability in child development? Hence, the objective of this study was to know the nurses' understanding about vulnerability in child development.

\section{METHODOLOGY}

This was an exploratory, qualitative study conducted in 39 Municipal Health Units (MHUs) carrying out the Family Health Strategy Program (FHSP), located in health districts in the city of Curitiba, in the southern state of Paraná, which simultaneously presented the results of Social Inclusion (SI) and Quality of Domicile (QD) indicators equal to or less than the mean for the municipality (SI - 3.66; QD - 3.05). ${ }^{1}$ Based on the criteria established above, the chosen health districts were: Bairro Novo (SI - 3.23; QD - 2.98), Pinheirinho (SI - 3.30; QD - 2.96), CIC (SI - 3.34; $\mathrm{QD}$ - 3.02), Boqueirão (SI - 3.52; $\mathrm{QD}-3.05)$ and Cajuru (SI - 3.56; QD - 3.05). ${ }^{1,8}$

To recruit subjects, the researcher requested that the health authority of the MHU indicate, through local health planning, the area of its unit with greatest social and epidemiological risk. Consequently, the research subjects were 39 nurses who met the inclusion criteria, worked on MHUs teams in high-risk areas, had at least two full years of work in the FHSP, and agreed to sign the Free and Informed Consent Form. The nurses that did not meet the inclusion criteria, and who were on vacation, sick leave or absent for another reason, were excluded from the sample. 
Data collection occurred from February to March 2012, through individual, semi-structured interviews in which the following topics were discussed: aspects that harm child development during early childhood, situations harmful to child development that the nurses had experienced, and actions to promote child development that the nurses had practiced.

Analysis of the subjects' statements was performed through dialectical hermeneutics, based on the analysis matrix of child vulnerability in the face of adverse situations to child development. ${ }^{8}$ This matrix enabled a synthetic reading of a child's situation and that of their family, and an approximation with this phenomenon on the care praxis of health care teams that showed how this concept was understood in its experiences in the face of biological, behavioral, affective, contextual, economic, social and political-programmatic aspects. ${ }^{8}$

The data were presented and identified with the abbreviation (E) and numbered sequentially, ensuring the respondents' anonymity. The research proposal was approved by the Ethics Committee of the Health Sciences Department of the Universidade Federal do Paraná, under protocol n. 1170.095.11.6.

\section{RESULTS AND DISCUSSION}

The material in this article was extracted from a study that addressed the individual, social and programmatic dimensions of vulnerability in child development. ${ }^{8}$ The following categories emerged from the interpretation of the subjects' statements: weak family bonds, substance abuse and domestic violence, within the individual dimension of vulnerability.

\section{Weak family bonds}

The nurses state that weak family bonds are characterized by permissiveness at home, the presence or absence of the father and multiple partners of the mother. These fragile links can harm the child's affective ties, as well as stimuli for their development:

[...] there are a lot of social issues, the families are big and the family bonds are weak, and there is permissiveness within these family bonds, and a promiscuity that is very present [...] Just this week, I evaluated an eight-month old child who still doesn't crawl [...] so that child graph is all right, quite normal, but she has no stimulus within the home. Within an extremely unorganized family, completely broken, she totally missed out on opportunities for motor stimuli and now she's delayed, despite having a completely good physical condition. (E27); [...] there is no family tie, none, they are not married, sometimes they are partners, have multiple partners, so we start with the woman, and this ends up being reflected later, during their prenatal, and then, in the act of caring for the child (E11).

Statements E27 and E11 correlate family ties to a social standard of families constituted by formal marriage, pointing to weak family bonds for the child and permissiveness within the home. The subjects mention the ideal role of a traditional nuclear family, composed of a husband and wife, for the provision of proper care for their children. This concept of the family was historically and socially constructed by contemporary society, as the family, since the early 20th century, assumed a moral function and was no longer simply an entity of private law that conveys goods and its name to its offspring. ${ }^{10}$

Families have been constructed in new arrangements that go beyond the traditional nuclear family, and that can maintain their socializing function for children. The reality for many families around the world is that women are often the breadwinner for their children, many surviving on low incomes without the presence of a partner, and living with the violence of urban peripheries. ${ }^{11-12}$

According to the subjects interviewed, these weak family bonds directly reflect on the interaction between members of the family and the child, as well as on the stimuli for child development. This alludes to the need for experiences that children need to develop in order to acquire new motor skills and relationships with the people around them. ${ }^{6}$ Such experiences require caregivers that provide empathetic and supportive interactions, which can teach children to learn new life experiences, as well as enable them to learn to think and reason. The difficulties children may have with affective relationships in the family and the absence or deficiency of bonds with caregivers may result in significant impairment in cognitive and emotional functions. ${ }^{5}$

However, these situations do not occur in isolation, but can be conditioned by the economic and social situation of the communities, which suffer from lack of access to education, and inadequate jobs and conditions to raise their children, all of which imply the influence of economic 
policies with low public investments. ${ }^{11-13}$ Thus, the insertion of these families into society is impaired by the dependence of their members on the incomes of a few people, which are not necessarily directed to meet the needs of their children. ${ }^{11}$ This reality needs to be understood not only by the healthcare team in its care process, but also by the social support network and the state as a provider of economic and social policies that can mitigate these vulnerabilities. ${ }^{14-15}$

Thus, the recognition of weaknesses in family bonds has direct implications on the care practices of nurses, because the lack of bonds of those responsible for the child may influence adherence to the interventions and behaviors prescribed by professionals..$^{5.16}$

\section{Substance abuse}

For the respondents, the presence of substance abuse at home is an element that can generate adverse situations to child development, as it influences the affective ties and protection of the child:

[...] there are many mothers that are drug addicts, and so they do not participate and often times the children do not have the same family life. [...] the mother had four children. The last child, she didn't have any prenatal care, she used drugs day and night, spent nights outside, and these children, the older ones, stayed with their grandmother, and the youngest also did [...] the grandmother takes care of five at the same time, and he is a child who was not loved (E35); there was an HIV-positive mother, a crack user who received prenatal care in several units in Curitiba, and she came to ours at 36 weeks. Then we started the active search. She had a urinary tract infection, a bunch of stuff. She abandoned these children in children's services, and we had to actively search, because the child had syphilis (E2); [...] we see that. So for children of mothers who are drug addicts, it is much more complicated. It influences, it influences a lot [...]. I had two that I monitored, both children ended up having serious developmental and nutritional problems. They took a long time to walk, to talk, to communicate (E37); [...] that's because parents who use drugs don't accompany the child the way they should. So there's not that adherence that we would like, not on the vaccine issue, or accompanying in the unit, from prenatal care until the birth, and afterwards (E22); [...] this mother lives in a region very close to the river... we always says it's an alley [...], and this child has a development problem, had speech delay and everything, and this child ended up dying because the mother, her problem with drugs, she lay on top of the baby and the baby died. [...] I've seen mothers who are drug users. We have the issue of a child whose mother used drugs throughout the prenatal period. This child had a complication, had to be referred to a specialist, and they are children who are still monitored today (E9); [...] we kept visiting her, a crack user; at first she carried the baby to stay with her under the bridge, with her husband, and they spent the entire night using crack, with the little baby there, and because of the toxic fumes the baby started to have problems. So sometimes she felt bad (E31).

In the statements E35 and E2, the subjects point to the presence of drugs in the daily lives of families as an element that undermines family bonds and the protection of children. One study shows that a major stress factor to child development has been substance abuse by parents. About $10 \%$ of children under the age of five lived with parents who abused substances in the past. ${ }^{17} \mathrm{In}$ addition, another study shows that families with substance abuse by parents had higher rates of mental illness, unemployment, domestic violence, delinquency, and greater reliance on social services, ${ }^{18}$ a fact that generates anguish, trauma and damage to children's development. ${ }^{19}$

Within the context of affective ties and drugs, nurses E35 and E2 mention the abandonment of children by their mothers. However, this motherchild relationship is primordially correlated by cultural and psychological influences and the education that the mother had in childhood. In this sense, it is necessary to understand the meaning that the abandonment of a child by his mother may have. ${ }^{20}$ This may be manifested in actions, often times, of the meaning of recognizing her inability to raise the child, or her rejection of him, or the frustration of her maternal love and desire. There is evidence that mothers who abandon their children suffer from exclusion, and abandon because they were also abandoned by public policies and society. ${ }^{20}$

Statements E37 and E22 point to the association between drug abuse by mothers and lack of care for their children's health or developmental stimuli. Studies show that drug abuse affects mothers' priorities for their children, with consequent negative effects on their consistency of care and supervision, which may have a negative influence on child development. ${ }^{18,21}$

Statements E9 and E31 are related to maternal consumption of psychoactive substances 
such as alcohol and other drugs, and their effect on the protection and safety of the child. Such situations may result in negligence in care, injury, household accidents and deaths related to traffic accidents, as well as a greater chance that the children become drug addicts or abusers themselves. ${ }^{17}$

One study shows that mistreatment of children, including child abuse and neglect, is an important public health problem, and estimates that in the United States alone, 872 thousand children are abused and 1,500 die as a result of this abuse, per year. ${ }^{22}$ Most children born with low birth weight and physical difficulties, and learning, emotional and social disabilities, could have these situations prevented if they were protected from early abuse and neglect, which makes them vulnerable to changes in the central nervous system. ${ }^{15,23}$

In concordance with statement E9, there is evidence that growth deficiency, psychomotor developmental delay, microcephaly, fine motor dysfunction and facial dimorphism, cleft palate and cardiac anomalies are related to drug use by the mother during the prenatal period. There may also be late manifestations, such as changes in intellectual and psychomotor ability, learning, attention and behavior. ${ }^{5,24}$ Another study shows that drug use during pregnancy is more common among women who receive delayed, limited or no prenatal care. On the other hand, pregnant women who use drugs and receive adequate prenatal care generally have better results in the birth and health of their children..$^{25}$

Statement E31 corroborates a study that shows that drug use by parents can cause functional impairment of their children, and deficits in their development are attributed to abuse by caregivers who are drug users. ${ }^{17}$ There is evidence that children of addicted parents tend to enter orphanages at younger ages, and are more likely to remain in foster care longer than abused children from families not affected by drug use. Similarly, children whose parents abused substances are twice as likely to suffer from physical or sexual abuse, compared to children of parents that are nonusers. ${ }^{18}$

The data discussed show that drug addiction is an aspect that impacts nursing care for child development, due to the lack of affective bonds and protective actions for the child. ${ }^{5}$ Such situations require a fair and comprehensive care process from nurses and healthcare teams in conjunction with other sectors of society in the legal and social spheres. . $^{3,5,16}$

\section{Domestic violence}

The respondents cite domestic violence as an adverse situation to children's physical protection, which can influence their development:

[...] Here in our area we have many at-risk and vulnerable children; I think the family, the family base, family structure greatly influences these cases; here we have children living with drug addiction at home, with domestic violence (E12); [...] the violence compromised the child, the child ended up having to do outpatient treatment [in] the children's CAPS [Psychosocial Care Center]; he failed to perform well, and today continues to receive treatment, a treatment that is not continuous, a treatment that begins, stops, improves, returns. So it was through the violence itself that exists in the region and the drug addiction (E7); [...] the environment in which the child is living, if substance abuse is present in the environment, if there is domestic violence, I think all of this, I'm not just talking about the structural part of the child, the physical part, but also the psychological part, all will have a consequence, when this child comes to adolescence and adulthood (E25); [...] you go to people's houses, you see the conditions. It's not enough to only look sometimes at the office, you really have to go to people's homes; it's what causes them to be the way they are, the environment in which they live [...] the father and mother quarreling, the environments of the parents (E15).

In the statements E12, E7 and E25, the nurses refer to the presence of violence as a consequence of drug use within the household. This focus supports a study that shows the presence of drugs and violence within the family as a reality in many countries around the world. ${ }^{17}$ It also corroborates other studies showing that, in many cases, substance abuse by parents is a factor that stimulates the expression of violence through aggression and attitudes of neglect towards their children. ${ }^{14,18,21}$

Furthermore, it is known that abuse of children generates short and long-term effects on their mental and physical health and psychosocial wellbeing. Another study found that abuse has consequences on child development, including signs of post-traumatic stress in childhood and adolescence, emotional and behavioral difficulties in adulthood, substance abuse in adolescence and adulthood, and suicidal, aggressive, and victim behavior. ${ }^{22}$ 
In statement E15, the nurse cites violence as a negative component in intra-family relationships. This result supports a reference that states that the psycho-emotional development of a child can be impeded by such situations. ${ }^{5}$ Rather than children receiving protection from their caregivers, in many cases they coexist with deleterious situations that can impede problem solving, language, memory and social skills. ${ }^{12,26}$

One study shows that the levels of child abuse are correlated with social inequalities in the community and social organization in urban environments, such as lack of infrastructure, poor housing, lack of social support and violence in the community. ${ }^{21}$ Similarly, another study indicates that low socioeconomic status, defined in terms of family income, is strongly associated with child neglect, and children from low-income families are five times more likely to be abused. ${ }^{18}$

Statements E12, E7 and E25 corroborate a study conducted in China, which showed that violence suffered by children is a global problem that transcends cultural, class, education, income and ethnic boundaries. This draws attention to the context in which violence between intimate partners and abuse coexist in a family. ${ }^{27}$ Although the family is represented as a location for protection, safety and affection for the child, in many cases children are abused within their family environment, often triggered by family conflicts. ${ }^{14}$

In another study, the authors show that domestic violence can occur as physical, verbal and emotional abuse such as aggression, dominance and control. ${ }^{28}$ This violence and aggression are largely related to affective poverty, leading to family breakdown, and the children of these families develop in an environment of insecurity, combined with shame and social embarrassment. ${ }^{19}$ In many cases, these children will grow and reproduce the behavioral patterns of their families, becoming aggressive people prone to crime and violence. $^{29}$

The results in this category point to contradictory official discourse from a state that professes to protect families and children, but in practice marginalizes and is absent from their lives - a notorious situation in the peripheries of large urban centers. ${ }^{30}$ Therefore, the authors of this study urge the formulation of public policy interventions that enable violence prevention and treatment of those who are suffering from substance abuse.
Thus, domestic violence shows the epidemiological transition to chronic health conditions that are an important aspect of care practice by nursing to promote child development. ${ }^{5,9}$ Because it is a complex phenomenon that surpasses the biologicist paradigm, nurses need to intervene through linkages with other sectors of society that protect children. ${ }^{4}$

\section{FINAL CONSIDERATIONS}

In the individual dimension of vulnerability, nurses understand the influence of affective and behavioral elements on family bonds and the care and protection of children. In the subjects' statements, there is a focus on the influence of the marital status of the parents, and the destructive potential of addiction and violence in families, especially on children. This view, however, does not correlate the expression of individual wear of the elements of this dimension of vulnerability as results of capitalist society, gender inequality and lack of a social support network.

The subjects of the study cite the expression of individual processes that are reflections of post-modern society, and understand this societalfamily relationship as an adverse situation to child development. These individual processes can be understood as an expression of the health-disease process of the family, which manifests its limitations in childcare, and the need for an inclusive and egalitarian society that seeks to share its resources for the welfare of all its citizens.

The data indicate the need for nurses to improve their care technologies that focus on family relationships, substance abuse and the protection of children exposed to domestic violence. They also show that by using the concept of vulnerability in their daily work, nurses and family health teams can conduct a critical review of their practices, with a view towards comprehensive care and the complexity of the concept of health, as their application in child care promotes reorientation of the care model, thus overcoming the biologicist and fragmented concept of child development.

This study has range limitations of reality, considering that it was developed with qualitative data, which are statements made by people, and do not always reflect reality in its totality. Thus, the authors recognize the need for further studies that seek to advance in structuring the concept of vulnerability in the field of child development. 


\section{REFERENCES}

1. Mazza VA, Chiesa AM. Family needs on child development in the light of health promotion. Online Braz J Nurs [online]. 2008 [acesso 2012 Out 01]; 7(3). Disponível em: http://www. objnursing.uff.br/index.php/nursing/article/ view/j.1676-4285.2008.1852

2. Apostólico MR, Cubas MR, Altino DM, Pereira KCM, Egry EY. Contribuição da CIPESC na execução das políticas de atenção à saúde da criança no município de Curitiba, Paraná. Texto Contexto Enferm. 2007 Jul-Set; 16(3):453-62.

3. Veleda AA, Soares MCF, Cézar-Vaz MR. Fatores associados ao atraso no desenvolvimento em crianças, Rio Grande, Rio Grande do Sul, Brasil. Rev Gauch Enferm. 2011 Mai-Jun; 32(1):79-85.

4. Ribeiro MO, Sigaud CHS, Rezende MA, Veríssimo MLÓR. Desenvolvimento infantil: a criança nas diferentes etapas de sua vida. In: Fujimori E, Ohara CVS, organizadoras. Enfermagem e a saúde da criança na atenção básica. Barueri (SP): Manole; 2009. p. 61-90.

5. Brazelton TB, Greenspan SI. As necessidades essenciais das crianças: o que toda criança precisa para crescer, aprender e se desenvolver. Porto Alegre (RS): Artmed; 2002.

6. Mustard JF. Early human development - Equity from the start - Latin America. Rev Lat Am Cienc Soc Niñez Juv. 2009 Jul-Dec; 7(2):639-80.

7. Ayres JRCM, Paiva V, França Junior I. From natural history of disease to vulnerability. In: Parker R, Sommer M. Routledge handbook in global public health. New York (US): Routledge; 2011. p. 98-107.

8. Silva DI, Chiesa AM, Veríssimo MLOR, Mazza VA. Vulnerability of children in adverse situations to their development: proposed analytical matrix. Rev Esc Enferm USP. 2013; 47(6):1397-402.

9. Shonkoff JP, Wood DL, Dobbins MI, Earls MF, Garner AS, McGuinn L, et al. The lifelong effects of early childhood adversity and toxic stress. Pediatrics. 2012 Jan; 129(1):232-46.

10. Ariès P. História social da criança e da família. Rio de Janeiro (RJ): Zahar; 1981.

11. Andrade SA, Santos DN, Bastos AC, Pedromônico MRM, Almeida-Filho N, Barreto M. Ambiente familiar e desenvolvimento cognitivo infantil: uma abordagem epidemiológica. Rev Saude Publica. 2005 Ago; 39(4):606-11.

12. Radcliff E, Racine EF, Huber LRB, Whitaker BE. Association between family composition and the well-being of vulnerable children in Nairobi, Kenya. Matern Child Health J. 2012 Ago; 16(6):1232-40.

13. Bittar DB, Nakano AMS. Violência intrafamiliar: análise da história de vida de mães agressoras e toxicodependentes no contexto da família de origem. Texto Contexto Enferm. 2011 Jan-Mar; 20(1):17-24.
14. Mustard JF. Free market capitalism, social accountability and equity in early human (child) development. Padiatr Child Health. 2008 Dez; 13(10):839-42.

15. Alexandre AMC, Labronici LM, Maftum MA, Mazza VA. Mapa da rede social de apoio às famílias para a promoção do desenvolvimento infantil. Rev Esc Enferm USP. 2012 Abr; 46(2):272-9.

16. Moreira MDS, Gaíva MAM. Acompanhamento do crescimento e desenvolvimento infantil: análise dos registros das consultas de enfermagem. Rev Pesqui Cuid Fundam. 2013 Abr-Jun; 5(2):3757-66.

17. Substance abuse and mental health services administration, office of applied studies. The NSDUH report: children living with substancedependent or substance-abusing Parents: 2002 to 2007. Rockville (US): MD: SAMHSA; 2009.

18. Onigu-Otite EC, Belchera HME. Maternal substance abuse history, maltreatment, and functioning in a clinical sample of urban children. Child Abuse Negl. 2012 Jun; 36(6):491-7.

19. Gabatz RIB, Padoin SMM, Neves ET, Terra MG. Fatores relacionados à institucionalização: perspectivas de crianças vítimas de violência intrafamiliar. Rev Gauch Enferm. 2010 Dez; 31(4):670-7.

20. Soejima CS, Weber LND. O que leva uma mãe a abandonar um filho? Aletheia. 2008 Jul-Dez; 28:17487.

21. Dakil SR, Sakai C, Lin H, Flores G. Recidivism in the child protection system: Identifying children at greatest risk of reabuse among those remaining in the home. Arch Pediatr Adolesc Med. 2011 Nov; 165(11):1006-12.

22. Kaslow NJ, Thompson MP. Associations of child maltreatment and intimate partner violence with psychological adjustment among low SES, African American children. Child Abuse Negl. 2008 Sep; 32(8):888-96.

23. Shonkoff JP. Protecting brains, not simply stimulating minds. Science. 2011 Aug; 333(6045):982-3.

24. Souza LHRF, Santos MC, Oliveira LCM. Padrão do consumo de álcool em gestantes atendidas em um hospital público universitário e fatores de risco associados. Rev Bras Ginecol Obstet. 2012 Jul; 34(7):296-30.

25. Roberts SCM, Pies C. Complex calculations: how drug use during pregnancy becomes a barrier to prenatal care. Matern Child Health J. 2010 Apr; 15(3):333-41.

26. Nobre FSS, Costa CLA, Oliveira DJ, Cabral DA, Nobre GC, Caçola P. Análise das oportunidades para o desenvolvimento motor (affordances) em ambientes domésticos no Ceará - Brasil. J Hum Growth Dev. 2009 Abr; 19(1):9-18

27. Chan KL. Children exposed to child maltreatment and intimate partner violence: a study of co- 
occurrence among Hong Kong Chinese families. Child Abuse Negl. 2011 Jul; 35(7):532-42.

28. Karakurt G, Cumbie T. The relationship between egalitarianism, dominance, and violence in intimate relationships. J Fam Violence. 2012 Feb; 27(2):115-22.

29. Milletich RJ, Kelley ML, Doane AN, Pearson MR.
Exposure to interparental violence and childhood physical and emotional abuse as related to physical aggression in undergraduate dating relationships. J Fam Violence. 2010 Oct; 25(7):627-37.

30. Fleury S. Militarização do social como estratégia de integração - o caso da UPP do Santa Marta. Sociologias. 2012 Mai-Ago; 14(30):194-222. 